\title{
Proses Penyelesaian Sengketa Gugatan Lelang Kepemilikan Sertifikat Hak Milik Nasabah terhadap PT. Bank Panin Indonesia (Studi Putusan No: 209/Pdt.G/2019/PN Tjk)
}

\author{
Erlina $^{1}$, Risti Dwi Ramasari², Rizky Ananda ${ }^{3}$ \\ ${ }_{1,2,3}$ Fakultas Hukum Universitas Bandar Lampung \\ Jalan ZA Pagar Alam No. 29 Labuhan Ratu Kecamatan Kedaton Kota Bandar Lampung, 35142, Indonesia \\ Correspondence email: erlina@ubl.ac.id, risti@ubl.ac.id, rizkyananda0310@gmail.com
}

\begin{abstract}
Abstrak. Bank merupakan suatu lembaga keuangan yang berperan penting dalam perekonomian suatu negara. Kredit merupakan pinjaman yang diajukan untuk membeli sesuatu dan peminjam melakukan pembayaran dengan sistem angsuran sesuai dengan ketentuan yang berlaku. Salah satu hal yang dipersyaratkan bank sebagai kreditur dalam pemberian kredit yaitu adanya perlindungan berupa jaminan yang harus diberikan debitur guna menjamin pelunasan utangnya demi keamanan dan kepastian hukum. Pada dasarnya kreditur pemegang jaminan kebendaan memiliki hak untuk mengeksekusi barang jaminan untuk dijual secara lelang guna pembayaran utang debitur jika debitur lalai melaksanakan kewajibannya berdasarkan perjanjian kredit atau biasa disebut dengan wanprestasi Salah satu sengketa gugatan lelang kepemilikan sertifikat antara debitur atau nasabah dengan kreditur atau lembaga perbankan tepatnya antara nasabah dan PT Bank Panin Indonesia dengan putusan nomor 209/Pdt.G/2019/PN Tjk. Permasalahan masalah di dalam peneitian ini adalah apakah faktor penyebab terjadinya dan bagaimana proses penyelesaian sengketa gugatan lelang kepemilikan sertifikat hak milik nasabah terhadap PT Bank Panin Indonesia. Penelitian ini menggunakan pendekatan penelitian yuridis normatif dan yuridis empiris. Pada penelitian ini menggunakan sumber data sekunder dan data primer. Teknik pengumpulan data yang digunakan melalui studi kepustakaan, observasi dan wawancasara. Analisis data dengan yuridis kualitatif. Bahwa faktor penyebab terjadinya Sengketa Gugatan Lelang Kepemilikan Sertifikat Hak Milik Nasabah Terhadap PT Bank Panin Indonesia Studi Pada Putusan Nomor 209/Pdt.G/2019/PN Tjk yang mana bahwa Penggugat merupakan Debitur pada Tergugat. Akibat Penggugat tidak mampu membayar Kredit yang telah diberikan oleh PT Bank Panin Indonesia selaku Kreditur maka dilakukan lelang dengan nilai limit sebesar Rp 1.470.000.000 (satu milyar empat ratus tujuh puluh juta rupiah). Akibat hal tersebut Penggugat menyatakan Tergugat telah melakukan Perbuatan Melawan Hukum yang merugikan Penggugat. Proses Penyelsaian Sengketa dilakukan melalui Non-Litigasi tidak memberikan hasil maka selanjutnya dilakukan melalui Litigasi. Gugatan Perbuatan Melawan Hukum yang diajukan oleh Pengugat terhadap PT Bank Panin Indonesia dinyatakan tidak dapat diterima. Disarankan bagi masyarakat khususnya agar dapat lebih memahami dan memperhitungkan serta mempertimbangkan dalam mengajukan pengajuan kredit kepada lembaga perbankan karena memiliki resiko kehilangan aset yang dijaminkan kepada lembaga perbankan. Untuk lembaga perbankan agar dapat memberikan penjelasan yang sangat jelas saat terjadinya perjanjian kredit yang dilakukan agar tidak terjadi gugatan sengketa karena kesalahpahaman antara lembaga perbankan selaku kreditur terhadap debiturnya di kemudian hari
\end{abstract}

Kata Kunci: Penyelsaian Sengketa Gugatan Lelang; Sertifikat Hak Milik; Nasabah Debitur

\begin{abstract}
Bank is a financial institution that plays an important role in a country's economy. Credit is a loan that is submitted to buy something and the borrower makes payments by installments in accordance with applicable regulations. One of the things that is required by banks as creditors in providing credit is protection in the form of guarantees that must be provided by the debtor to ensure repayment of their debts for security and legal certainty. Basically the creditor holding the material guarantee has the right to execute collateral for sale by auction for debtor debt payment if the debtor fails to carry out his obligations based on a credit agreement or commonly referred to as default One of the dispute over a certificate ownership auction between the debtor or customer and the creditor or banking institution to be precise between the customer and PT Bank Panin Indonesia with decision number 209 / Pdt.G / 2019 / PN Tjk. The problem in this research is whether the factors that cause it to occur and how is the process of dispute resolution on the auction claim ownership certificate of customer ownership against PT Bank Panin Indonesia. This study uses a juridical normative and empirical juridical research approach. In this study using secondary data sources and primary data. Data collection techniques used through literature study, observation and interviews. Qualitative juridical data analysis. That the factors causing the dispute over the Auction of Customer's Ownership Certificate Ownership against PT Bank Panin Indonesia studied on Decision Number 209 / Pdt.G / 2019 / PN Tjk in which the Plaintiff was a Debtor to the Defendant As a result of the Plaintiff being unable to pay the Credit that was given by PT Bank Panin Indonesia as the Creditor, an auction was conducted with a limit value of Rp. 1,470,000,000 (one billion four hundred seventy million rupiah). As a result of this, the Plaintiff stated that the Defendant had committed illegal acts which caused the loss of the Plaintiff. The Dispute Resolution process carried out through Non-Litigation does not produce results, then it is carried out through Litigation. The Lawsuit against the Law filed by the Plaintiff against PT Bank Panin Indonesia was declared unacceptable. It is recommended that the public, in particular, be able to better understand and take into account and consider applying for credit to banking institutions because they have the risk of losing assets that are guaranteed to banking institutions. For banking institutions to be able to provide a very clear explanation when a credit agreement is made to avoid a lawsuit due to a misunderstanding between the banking institution as the creditor against the debtor at a later date.
\end{abstract}


Erlina, Risti Dwi Ramasari dan Rizky Ananda, Proses Penyelesaian Sengketa Gugatan Lelang Kepemilikan Sertifikat Hak Milik Nasabah terhadap PT. Bank Panin Indonesia (Studi Putusan No: 209/Pdt.G/2019/PN Tjk)

Keywords: Settlement of Tender Claims Dispute; Certificate Right of Ownership; Debtor Customers

\section{PENDAHULUAN}

Bank merupakan suatu lembaga keuangan yang berperan penting dalam perekonomian suatu negara. Semakin berkembang industri perbankan maka semakin baik pula pertumbuhan ekonomi negara tersebut. Bank sebagai lembaga keuangan berfungsi untuk menghimpin dan menyalurkan dana kepada masyarakat dalam rangka pemerataan, pertumbuhan ekonomi dan stabilitas nasional kearah peningkatan kesejahteraan rakyat.

Masyarakat dalam usaha memenuhi kebutuhannya membutuhkan suatu pendananaan dari bank, yaitu salah satunya dengan menggunakan jasa perkreditan. Menurut Undang - Undang Perbankan No.10 Tahun 1998 tentang Perbankan bahwa Kredit adalah penyediaan uang atau tagihan, berdasarkan persetujuan atau kesepakatan pinjam meminjam antara bank dengan pihak lain yang mewajibkan pihak peminjam melunasi utangnya setelah jangka waktu tertentu dengan pemberian bunga.

Kredit berasal dari bahasa Italia, credere yang artinya kepercayaan, yaitu kepercayaan dari kreditur bahwa debitur akan mengembalikan pinjaman beserta bunganya sesuai dengan perjanjian kedua belah pihak dan kreditur percaya bahwa kredit itu tidak akan macet. ${ }^{1}$ Kredit merupakan pinjaman yang diajukan untuk membeli sesuatu dan peminjam melakukan pembayaran dengan sistem angsuran sesuai dengan ketentuan yang berlaku. ${ }^{2}$ Jadi kredit dapat diartikan sebagai dana yang didapat dari pihak pemberi pinjaman dan kemudian dikembalikan secara berjangka beserta dengan bunga pinjaman.

Dalam pemberian kredit terdapat unsur unsur yang diberikan selaku pemberi kredit yakni kepercayaan dari bank (kreditur) terhadap peminjam (debitur) dengan dilandasi adanya kesepakatan pinjam meminjam. Salah satu hal yang dipersyaratkan bank sebagai kreditur dalam pemberian kredit yaitu adan perlindungan berupa jaminan yang harus diberikan debitur guna menjami pelunasan utangnya demi keamanan dan kepastian hukum, khususnya apabi setelah jangka waktu yang diperjanjikan, debitur tidak meluasi hutangnya atau melakukan wanprestasi.

Sesuai dengan tujuannya, barang jaminan baik berupa benda bergerak maupun benda tidak bergerak tersebut bukan untuk dimiliki secara pribadi oleh kreditur, karena perjanjian utang-piutang atau perjanjian kredit bukanlah merupakan suatu perjanjian jual beli yang mengakibatkan perpindahan hak milik atas suatu barang, akan tetapi barang jaminan tersebut dipergunakan untuk melunasi utang dengan cara sebagaimana diatur dalam peraturan yang berlaku, yaitu barang dijual secara lelang dimana hasilnya untuk melunasi utang debitur, dan apabila terdapat sisa maka hasilnya akan dikembalikan kepada debitur. ${ }^{3}$

Bentuk jaminan yang paling banyak digunakan sebagai agunan dalam perjanjian kredit bank adalah hak atas tanah, baik dengan status hak milik, hak guna usaha, hak guna bangunan maupun hak pakai, karena pada umumnya memiliki nilai atau harga yang tinggi dan terus meningkat, sehingga dalam hal ini sudah selayaknya apabila debitur sebagai penerima kredit dan kreditur sebagai pemberi fasilitas kredit serta pihak lain terkait memperoleh perlindungan melalui suatu lembaga hak jaminan yang kuat dan dapat memberikan kepastian hukum. ${ }^{4}$

Jika kredit yang disalurkan mengalami kemacetan, maka langkah yang dilakukan adalah menyelamatan kredit tersebut. Jika memang masih bisa dibantu, maka tindakan yang tepat adalah menambah jumlah kredit atau dengan memperpanjang jangka waktunya. Dan apabila memang sudah tidak dapat diselamatkan kembali, maka tindakan terakhir bagi bank adalah menyita jaminan yang telah dijamikan oleh nasabah.

Dalam proses pemberian kredit, sering terjadi bahwa pihak kreditur dirugikan ketika pihak debitur melakukan wanprestasi, sehingga diperlukan suatu aturan hukum dalam pelaksanaan pembebanan yang tertuang dalam suatu perjanjian kredit, yang bertujuan untuk memberikan kepastian dan perlindungan hukum bagi pihak-pihak terkait, khususnya bagi pihak kreditur apabila debitur wanprestasi atau tidak memenuhi kewajibannya. Wanprestasi adalah pelaksanaan perjanjian yang tidak tepat waktunya atau dilakukan tidak menurut selayaknya atau tidak dilaksanakan sama sekali. ${ }^{5}$

Pada dasarnya kreditur pemegang jaminan kebendaan memiliki hak untuk mengeksekusi barang jaminan untuk dijual secara lelang guna pembayaran utang debitur jika debitur lalai melaksanakan kewajibannya berdasarkan perjanjian kredit atau biasa disebut dengan wanprestasi. Pemberian hak kepada kreditur untuk mengeksekusi jaminan kebendaan yang diberikan oleh debitur dapat kita lihat dalam Kitab Undang Undang Hukum Perdata serta beberapa peraturan perundang-undangan.

\footnotetext{
${ }^{1}$ Malayu SP Hasibuan.2005. Dasar-Dasar Perbankan. Bumi Aksara. Jakarta. hlm 87

${ }^{2}$ Adri Natar 2008. Solusi Cerdas Mengatasi Hutang Kredit. Penebar Plus. Jakarta. hlm 10

${ }^{3}$ Gatot Supramono. 1996. Perbankan dan Masalah Kredit Suatu Tinjauan Yuridis.Jakarta: Djambatan. Jakarta. hlm. 75.

${ }^{4}$ Yudha Pandu. 2008. Himpunan Peraturan Perundang-Undangan Jaminan Fidusia dan Hak Tanggungan. Indonesia Legal Center Publishing. Jakarta. hlm.65.

${ }^{5}$ M Yahya Harahap.1996. Segi-segi Hukum Perjanjian. Alumni. Bandung. hlm. 60.
} 
Erlina, Risti Dwi Ramasari dan Rizky Ananda, Proses Penyelesaian Sengketa Gugatan Lelang Kepemilikan Sertifikat Hak Milik Nasabah terhadap PT. Bank Panin Indonesia (Studi Putusan No: 209/Pdt.G/2019/PN Tjk)

Apabila kredit macet terjadi karena debitur tidak melaksanakan prestasinya sebagaimana terdapat dalam perjanjian kredit, maka sebelum melakukan eksekusi barang jaminan, debitur harus terlebih dahulu dinyatakan wanprestasi, yang dilakukan melalui putusan pengadilan. Untuk itu kreditur harus menggugat debitur atas dasar wanprestasi. Akan tetapi sebelum menggugat debitur, kreditur harus melakukan somasi terlebih dahulu yang isinya agar debitur memenuhi prestasinya. Apabila debitur tidak juga memenuhi prestasinya, maka kreditur dapat menggugat debitur atas dasar wanpretasi, dengan mana apabila pengadilan memutuskan bahwa debitur telah wanprestasi, maka kreditur dapat melakukan eksekusi atas barang jaminan yang diberikan oleh debitur. ${ }^{6}$

Salah satu sengketa gugatan lelang kepemilikan sertifikat antara debitur atau nasabah dengan kreditur atau lembaga perbankan tepatnya antara nasabah dan PT Bank Panin Indonesia dengan putusan nomor 209/Pdt.G/2019/PN Tjk. Berdasarkan uraian latar belakang yang telah dijelaskan tersebut, maka dalam penelitian hukum ini penulis menyusun penulisan skripsi ini dengan judul : "Proses Penyelesaian Sengketa Gugatan Lelang Kepemilikan Sertifikat Hak Milik Nasabah Terhadap PT Bank Panin Indonesia (Studi Putusan No: 209/Pdt.G/2019/PN Tjk)"

Permasalahan masalah di dalam peneitian ini adalah sebagai berikut:

1. Apakah Faktor Penyebab Terjadinya Sengketa Gugatan Lelang Kepemilikan Sertifikat Hak Milik Nasabah Terhadap PT Bank Panin Indonesia (Studi Putusan No: 209/Pdt.G/2019/PN Tjk.?

2. Bagaimana Proses Penyelesaian Sengketa Gugatan Lelang Kepemilikan Sertifikat Hak Milik Nasabah Terhadap PT Bank Panin Indonesia (Studi Putusan No: 209/Pdt.G/2019/PN Tjk.?

\section{METODE}

Penelitian ini menggunakan pendekatan penelitian yuridis empiris yakni penelitian hukum mengenai pemberlakuan atau implementasi ketentuan hukum normatif secara in action pada setiap peristiwa hukum tertentu yang terjadi dalam masyarakat. ${ }^{7}$ Dan penekitian ini juga menggunakan pendekatan yuridis normatif. Pendekatan yuridis normatif adalah pendekatan yang dilakukan berdasarkan bahan hukum utama, menelaah hal yang bersifat teoritis yang menyangkut asas-asas hukum, konsepsi hukum, pandangan dan doktrin-doktrin hukum, peraturan dan sistem hukum dengan menggunakan data sekunder, diantaranya asas, kaidah, norma dan aturan hukum yang terdapat dalam peraturan perundang-undangan dan peraturan lainnya, dengan mempelajari buku-buku, peraturan perundang undangan dan dokumen lain yang berhubungan dengan penelitian yang akan dibahas. Pada penelitian ini menggunakan sumber data yakni bahan hukum primer, bahan hukum sekunder dan bahan hukum tersier.

\section{HASIL DAN PEMBAHASAN}

Faktor Penyebab Terjadinya Sengketa Gugatan Lelang Kepemilikan Sertifikat Hak Milik Nasabah Terhadap PT Bank Panin Indonesia (Studi Putusan No: 209/Pdt.G/2019/PN Tjk)

1. Bahwa Penggugat merupakan Debitur pada Tergugat dan telah menerima fasilitas kredit sebesar Rp 1.600.000.000 (satu milyar enam ratus juta rupiah) dengan jangka waktu kredit 10 Tahun atau 120 (seratus dua puluh) bulan dimulai 13-12-2013 s/d jatuh tempo 13-12-2023 sebagaimana Perjanjian kredit No. 4 tertanggal 13 Desember 2013 yang dibuat dihadapan Notaris Jenmerdin, S.H.

2. Bahwa Penggugat menjaminkan 2 (dua) bidang tanah Tanah dan Bangunan yang terletak di Kelurahan Segala Mider Kecamatan Tanjung Karang Barat Kota Bandar Lampung yaitu:

a. Sertifikat hak milik nomor: 11119/Se. M, dengan surat ukur tanggal 15-08-2002 (Lima belas agustus tahun dua ribu dua) Nomor. 382/Se.M/2002 seluas 642 M2 (enam ratus empat puluh dua meter persegi).

b. Sertifikat Hak Milik Nomor 111120/Se.M, dengan surat ukur tanggal 15-08-2002 (lima belas Agustus tahun dua ribu dua) Nomor. 383/Se.M/2002 seluas 517 M2 (lima ratus tujuh belas meter persegi).

3. Bahwa dalam melakukan pembayaran, Penggugat beberapa kali mengalami masa sulit di tahun 2014 Pabrik Tapioka/Sagu milik Penggugat berhenti beroperasi dan upaya menjual pabrik seharga lebih kurang Rp. 5.000.000.000 (lima milyar rupiah) Nilai pasar berdasarkan Apraisal CBV Evaluation sebesar Rp.5.326.100.000,yang hingga saat ini belum terjual. Tahun 2014 penipuan dari suppier bahan baku singkong untuk pabrik tapioca ( Singkong) sebesar +/-Rp. 400.000.000,-dan dari penipuan dari pemilik tanah lahan tanam singkong sebesar +/- Rp.125.000.000,- sesuai LP di Polres Lampung Tengah Tahun 2016 Penggugat terkena penipuan investasi bodong di Jakarta sebesar Rp. 1.500.000.000 (satu milyar lima ratus juta rupiah) sesuai Laporan Polisi di Polda Metro Jaya Nomor LP/3586/VII/2018/PMJ/Dit tanggal 10 Juli 2016, namun Penggugat masih berupaya untuk melakukan pembayaran kepada Tergugat.

Bahwa pada tanggal 16 Agustus 2019 Penggugat dipangggil ke Kantor Bank Panin oleh Tergugat diwakili oleh.Sdr.Dedi/staf Bank Panin disaksikan oleh Sdr.Made Partawiguna dan Sdr.Kadek (keduanya pegawai Bank

${ }^{6}$ https://www.hukumonline.com/klinik/detail/ulasan/lt50294244defee/langkah-langkah-penyelesaian-kredit-macet. Diakses Pada Tanggal 18 Otober 2020 Pada Pukul 14.45 wib.

${ }^{7}$ Abdulkadir Muhammad. 2004. Hukum dan Penelitian Hukum. Citra Aditya Bakti. Jakarta. hlm. 134. 
Panin), terlampir bukti surat penolakan dari Penggugat dan diminta untuk menandatangani AJB (Akta Jual Beli) atas jaminan milik Penggugat Sertifikat Hak Milik No: 11119/Se. M, seluas 642 M2 (enam ratus empat puluh dua meter persegi) an.Fajar Sidik dan Sertifikat Hak Milik No. 111120/Se.M, seluas 517 M2 (lima ratus tujuh belas meter persegi) an.Fajar Sidik Apabila Penggugat bersedia tanda tangan AJB akan diberikan oleh Tergugat uang sebesar Rp.300.000.000,- (Tiga Ratus Juta Rupiah), namun Penggugat menolak, Pada saat yang bersamaan Penggugat membuat surat pernyataan meminta keringanan pelunasan sebesar Rp.1.000.000.000,- (Satu milyar Rupiah)

Jawaban permohonan keringanan pelunasan dari Tergugat kami peroleh 1 (satu) jam sebelum penutupan Lelang atau jam 13.00 Wib di hari Kamis tanggal 22 Agustus 2019 (bukti terlampir) dengan angka pelunasan yang disetujui oleh Bank Panin sebesar Rp.1.100.000.000, (Satu milyar seratus juta rupiah), dalam hal ini ada kejanggalan dan hal tidak wajar Penggugat bisa menyelesaikan pelunasan dalam hitungan jam dihari yang bersamaan lelang, meskipun saat itu ada calon pembeli rumah milik Penggugat yang menawar di harga Rp.3.000.000.000,-(Tiga milyar rupiah) namun membutuhkan proses waktu setidaknya 2-3 hari untuk mengurus pajak, notaries, ajb dll.

4. Bahwa Penggugat mendapatkan informasi lelang secara lisan dari Tergugat, Pada tanggal 20 Agustus 2019 atau 2 (dua) hari sebelum lelang Penggugat mencari kebenaran informasi lelang dengan mendatangi Kantor KPKNL Jl Basuki Rahmat Bdl dan mencari pengumuman, namun tidak ditemukan adanya pengumuman lelang dipasang di kantor KPKNL Turut Tergugat 1, kemudian mendatangi Kantor Pengadilan Negeri dan bertemu Panitera Lelang Bpk.Ahyar, diperoleh keterangan agar mendatangi kantor Tergugat dan kemudian Penggugat mendatangi kantor Tergugat (Bank Panin Jl.Kartini Bdl) bertemu Sdr.Dedi/pegawai Bank Panin, diperoleh keterangan bahwa Tergugat tidak bersedia dipertemukan ke Kantor Pengadilan Negeri untuk mediasi dan menunda lelang serta Tergugat tidak bersedia memberikan waktu seminggu kepada Penggugat untuk menyelesaikan /pelunasan dan pada pokoknya pembicaraan tidak bisa diajak mediasi oleh Penggugat untuk duduk bersama menyelesaikan masalah.

5. Penggugat tidak pernah diberitahukan informasi sebelumnya baik secara lisan maupun melalui surat oleh Tergugat atau Turut Tergugat 1 atau pihak Pengadilan Negeri. Sebelum pelaksanaan lelang seharusnya Penggugat diberitahukan terlebih dahulu sebagaimana diatur dalam Pasal 1 angka 3 Peraturan Menteri Keuangan Republik Indonesia Nomor 27 /Pmk.06/2016 Tentang Petunjuk Pelaksanaan Lelang, yang menentukan "Pengumuman lelang adalah pemberitahuan kepada masyarakat tentang akan adanya Lelang dengan maksud unuk menghimpun peminat lelang dan pemberitahuan kepada pihak yang berkepentingan".

6. Bahwa Tergugat menyampaikan kepada Penggugat setelah diminta Penggugat dengan memberikan photocopy Pengumumam Lelang surat kabar setelah 10 (sepuluh ) hari pelaksanaan lelang. Adapun Pengumuman Lelang Eksekusi Pengadilan Negeri Kelas I A Tanjung Karang Tertanggal 15 Agustus 2019, yang dilaksanakan oleh Pengadilan Negeri Kelas I A Tanjung Karang berdasarkan penetapan Ketua Pengadilan Negeri Kelas I A Tanjung Karang Nomor 1/Pdt.Eks.HT/2017/PN.Tjk Tertanggal 14 Juni 2017, dengan perantara Turut Tergugat 1, akan dilakukan terhadap Jaminan Penggugat pada Tanggal 22 Agustus 2019 di Pengadilan Negeri Tanjung Karang, dengan harga nilai limit Rp 1.470.000.000 (satu milyar empat ratus tujuh puluh juta rupiah) dibawah Nilai Pasar dan Nilai Likuidasi.

Bahwa berdasarkan hal tersebut Pelaksanaan lelang yang dilaksanakan atas permohonan Tergugat dengan perantara Turut Tergugat 1 yang dilakukan tanpa pemberitahuan terlebih dahulu kepada Penggugat, nilai limit yang jauh dibawah harga pasar dan nilai likuidasi tersebut sangat merugikan Penggugat dan patut kiranya Tergugat dinyatakan telah melakukan suatu perbuatan yang melawan hukum sebagaimana dimaksud dalam Pasal 1365 Kitab Undang- Undang Hukum Perdata yang menyatakan "Tiap perbuatan yang melanggar hukum dan membawa kerugian kepada orang lain, mewajibkan orang yang menimbulkan kerugian itu karena kesalahannya untuk menggantikan kerugian tersebut".

\section{Proses Penyelsaian Sengketa Gugatan Lelang Kepemilikan Sertifikat Hak Milik Antara Nasabah Terhadap PT Bank Panin Indonesia (Studi Putusan No : 209/Pdt.G/2019/PN Tjk)}

Bahwa telah telah dilakukan upaya -upaya hukum terhadap pengugat yakni melalui:

1. Non Litigasi

Bahwa Majelis Hakim telah mengupayakan perdamaian di antara para pihak melalui mediasi sebagaimana diatur dalam Peraturan Mahkamah Agung Nomor 1 Tahun 2016 tentang Prosedur Mediasi di Pengadilan dengan menunjuk Zoya Haspita, S.H., M.H., Hakim pada Pengadilan Negeri Tanjung Karang, sebagai Mediator. Bahwa berdasarkan laporan Mediator tanggal 3 September 2019, upaya perdamaian tersebut tidak berhasil.

2. Litigasi

Dikarenakan upaya hukum secara Non Litigasi tidak memberikan hasil maka selanjutnya Tergugat melaksanakan lelang eksekusi sertifikat Hak Milik di Pengadilan Negeri Kelas I A Tanjung Karang. Selanjutnya Penggugat 
Erlina, Risti Dwi Ramasari dan Rizky Ananda, Proses Penyelesaian Sengketa Gugatan Lelang Kepemilikan Sertifikat Hak Milik Nasabah terhadap PT. Bank Panin Indonesia (Studi Putusan No: 209/Pdt.G/2019/PN Tjk)

melakukan gugatan Perbuatan Melawan Hukum kepada para Tergugat. Bahwa terhadap gugatan Penggugat tersebut Tergugat memberikan jawaban pada pokoknya sebagai berikut:

\section{Eksepsi Kompetensi Relatif}

1. Bahwa didalam Gugatannya, Penggugat telah menarik P.T. Bank Pan Indonesia, Tbk (PT Bank Panin, Tbk) sebagai Tergugat sedangkan KPKNL Bandar Lampung, Kepala Kantor Pertanahan Kota Bandar Lampung dan Koharudin Adhar adalah sebagai Turut Tergugat yang hanya tunduk dan patuh terhadap isi Putusan. Hal tersebut dapat disimpulkan dari Petitum Gugatan yang hanya meminta Ketua Pengadilan Negeri Kelas IA Tanjung Karang cq Yang Mulia Majelis Hakim dalam perkara a quo untuk menghukum Tergugat saja dan tidak dengan para Turut Tergugat.

2. Bahwa didalam Perjanjian Kredit Nomor 4 tertanggal 13 Desember 2013, yang menandatangani Perjanjian Kredit adalah Tuan Mustar dan Nyonya Laurensia Santina yang bertindak mewakili Direksi dan karenanya bertindak untuk dan atas nama Perseroan Terbatas PT. Bank Pan Indonesia, Tbk disingkat PT. Bank Panin, Tbk yang berkedudukan di Kota Jakarta Pusat.

3. Bahwa merujuk Pasal 1792 KUH Perdata yang berbunyi : Pemberian Kuasa adalah suatu persetujuan dengan mana seorang memberikan kekuasaan kepada seorang lain yang menerimanya, untuk dan atas namanya menyelenggarakan suatu urusan.

4. Bahwa berdasarkan ketentuan Pasal 1792 KUH Perdata tersebut, maka dapat disimpulkan bahwa Tuan Mustar dan Nyonya Laurensia Santina hanyalah bertindak selaku Kuasa dari PT. Bank Panin Indonesia, Tbk yang berkedudukan di Jakarta Pusat dan dengan demikian maka sudah seharusnya Gugatan a quo diajukan, diperiksa dan diputus oleh Pengadilan Negeri Jakarta Pusat dan bukannya oleh Pengadilan Negeri Kelas IA Tanjung Karang.

\section{Gugatan Kurang Pihak (Plurium Litis Consortium)}

1. Bahwa didalam Posita Gugatan, Penggugat secara tegas dan lugas mempermasalahkan hasil penilaian dari Kantor Jasa Penilai Publik Sudiono Awaludin dan Rekan atas Obyek Hak Tanggungan berupa :

a. Hak Milik No. 11119/Se.M atas sebidang tanah sebagaimana diuraikan dalam Surat Ukur tanggal 15 Agustus 2002 Nomor 382/Se.M/2002 seluas $642 \mathrm{~m} 2$ (enam ratus empat puluh dua meter persegi) dengan Nomor Identifikasi Bidang Tanah (NIB) 08.01.01.04.01841 dan Surat Pemberitahuan Pajak Terhutang Pajak Bumi dan Bangunan (SPPTPBB) Nomor Objek Pajak (NOP) 18.71.031.009.011-0061.0.

b. Hak Milik No. 11120/Se.M atas sebidang tanah sebagaimana diuraikan dalam Surat Ukur tanggal 15 Agustus 2002 Nomor 383/Se.M/2002 seluas $517 \mathrm{~m} 2$ (lima ratus tujuh belas meter persegi) dengan Nomor Identifikasi Bidang Tanah (NIB) 08.01.01.04.01842 dan Surat Pemberitahuan Pajak Terhutang Pajak Bumi dan Bangunan (SPPTPBB) Nomor Objek Pajak (NOP) 18.71.031.009.011-0061.0; Berikut dengan bangunan, tanaman dan hasil karya yang telah ada atau yang dikemudian hari akan ada, yang merupakan satu kesatuan dengan tanah hak tersebut, berdasarkan alat bukti berupa Sertipikat Hak Milik Nomor 11119/Se.M tanggal 4 November 2002 dan Sertipikat Hak Milik Nomor 11120/Se.M tanggal 4 November 2002, yang seluruhnya terletak di Jalan Pagar Alam Gg. Ulangan No. 8, Kelurahan Segala Mider, Kecamatan Tanjung Karang Barat, Kota Bandar Lampung, Provinsi Lampung; Akan tetapi Penggugat tidak menarik Kantor Jasa Penilai Publik Sudiono Awaludin dan Rekan sebagai Tergugat;

2. Berdasarkan Salinan Risalah Lelang Nomor 070/20/2018 tertanggal 7 Maret 2018, Salinan Risalah Lelang Nomor 261/20/2019 tertanggal 9 April 2019, Salinan Risalah Lelang Nomor 511/20/2019 tertanggal 27 Juni 2019 dan Salinan Risalah Lelang Nomor 735/20/2019 tertanggal 22 Agustus 2019, maka didapatkan Fakta bahwa Permohonan Lelang atas Obyek Hak Tanggungan dilakukan oleh Pengadilan Negeri Kelas I A Tanjung Karang, akan tetapi Penggugat juga tidak menarik Ketua Pengadilan Negeri Kelas I A Tanjung Karang sebagai Tergugat

3. Bahwa didalam Petitumnya, Penggugat secara jelas meminta agar Ketua Pengadilan Negeri Kelas IA Tanjung Karang cq Yang Mulia Majelis Hakim yang memeriksa perkara a quo untuk menyatakan batal demi hukum Sertipikat Hak Tanggungan Nomor 00815/2014 tanggal 20 Februari 2014, akan tetapi Penggugat tidak menarik PPAT yang membuat Akta Pemberian Hak Tanggunan;

4. Bahwa dengan tidak ditariknya Kantor Jasa Penilai Publik Sudiono Awaludin dan Rekan, Ketua Pengadilan Negeri Kelas IA Tanjung Karang dan PPAT yang membuat Akta Pemberian Hak Tanggungan sebagai Tergugat, maka telah terjadi error in persona dalam bentuk plurium litis consortium. Pihak yang bertindak sebagai Penggugat atau yang ditarik sebagai Tergugat tidak lengkap, masih ada orang yang mesti ikut bertindak sebagai Penggugat atau ditarik Penggugat dan dengan demikian sangat beralasan bagi Yang Mulia Majelis Hakim dalam perkara a quo untuk menolak Gugatan atau setidak-tidaknya menyatakan Gugatan tidak dapat diterima (Niet Onvaankelijke Veerklaard). 
Erlina, Risti Dwi Ramasari dan Rizky Ananda, Proses Penyelesaian Sengketa Gugatan Lelang Kepemilikan Sertifikat Hak Milik Nasabah terhadap PT. Bank Panin Indonesia (Studi Putusan No: 209/Pdt.G/2019/PN Tjk)

\section{Gugatan Penggugat adalah Kabur (Obscuur Libel)}

1. Bahwa selain Kompetensi Relatif dan kurang pihak dalam gugatan sebagaimana telah diuraikan diatas, Gugatan Penggugat juga adalah kabur dalam bentuk Kontradiksi Antara Posita dengan Petitum.

2. Bahwa didalam Positanya, Penggugat sama sekali tidak membahas mengenai permintaan Penggugat untuk diberikan waktu guna melaksanakan kewajibannya kepada Tergugat, akan tetapi didalam Petitum Penggugat meminta hal tersebut. Hal ini tentu saja sangat kontradiktif sehingga dapat dikategorikan sebagai Gugatan adalah kabur (Obscuure Libel).

3. Bahwa selain itu, didalam Gugatan tidak dirinci mengenai kerugian apa saja yang diderita oleh Penggugat sehingga Penggugat dapat menyimpulkan bahwa Penggugat telah mengalami kerugian sebesar Rp. 7.500.000.000,- (tujuh miliar lima ratus juta rupiah).

4. Bahwa berdasarkan uraian diatas, dapat dipastikan bahwa Penggugat tidak dapat merinci dan tidak dapat menjelaskan kerugiannya sehingga hal demikian adalah kabur (Obscuure Libel) dan oleh karena itu sangat beralasan agar Yang Mulia Majelis Hakim dalam perkara a quo untuk menyatakan menolak Gugatan Penggugat atau setidak-tidaknya menyatakan Gugatan tidak dapat diterima (Onvaankelijke Veerklaard).

Menimbang bahwa oleh karena gugatan Penggugat tidak dapat diterima, maka Penggugat harus dihukum untuk membayar biaya perkara; Memperhatikan ketentuan-ketentuan dalam $\mathrm{RBg}$ dan peraturan-peraturan lain yang bersangkutan dengan perkara ini Mengadili:

1. Dalam Provisi: Menolak Permohonan Provisi Penggugat

2. Dalam Eksepsi: Menerima Eksepsi Tergugat;

3. Dalam Pokok Perkara:

a. Menyatakan gugatan Penggugat tidak dapat diterima;

b. Menghukum Penggugat untuk membayar biaya perkara yang sampai hari ini ditetapkan sejumlah Rp2.576.000,00 (dua juta lima ratus tujuh puluh enam ribu rupiah).

Berdasarkan hal tersebut diatas maka dapat dianalisis bahwa Gugatan Perbuatan Melawan Hukum yang diajukan oleh Pengugat Fajar Sidik selaku nasabah terhadap PT Bank Panin Indonesia dinyatakan tidak dapat diterima. Bahwa Penggugat Fajar Sidik merupakan Debitur pada Tergugat dan telah menerima fasilitas kredit sebesar Rp 1.600.000.000 (satu milyar enam ratus juta rupiah) dengan jangka waktu kredit 10 Tahun atau 120 (seratus dua puluh) bulan sebagaimana Perjanjian Kredit yang dibuat dihadapan Notaris Jenmerdin, S.H. Penggugat menjaminkan 2 (dua) bidang Tanah dan Bangunan yang terletak di Kelurahan Segala Mider Kecamatan Tanjung Karang Barat Kota Bandar Lampung. Karena tidak bisa melakukan pembayaran kredit maka jaminan tersebut dilelang dengan harga nilai limit Rp 1.470.000.000 (satu milyar empat ratus tujuh puluh juta rupiah). Dikarenakan dalam pokok perkara gugatan Penggugat tidak dapat diterima maka Penggugat diminta untuk membayar biaya perkara yang ditetapkan sejumlah Rp2.576.000,00 (dua juta lima ratus tujuh puluh enam ribu rupiah).

\section{SIMPULAN}

Berdasarkan hasil penelitian dan pembahasan penulis menarik kesimpulan terkait dengan Faktor Penyebab dan Proses Penyelsaian Sengketa Gugatan Lelang Kepemilikan Sertifikat Hak Milik Nasabah Terhadap PT Bank Panin Indonesia Studi Pada Putusan No : 209/Pdt.G/2019/PN Tjk yakni sebagai berikut :

1. Bahwa faktor penyebab terjadinya Sengketa Gugatan Lelang Kepemilikan Sertifikat Hak Milik Nasabah Terhadap PT Bank Panin Indonesia Studi Pada Putusan No : 209/Pdt.G/2019/PN Tjk yang mana bahwa Penggugat merupakan Debitur pada Tergugat dan telah menerima fasilitas kredit sebesar Rp 1.600.000.000 (satu milyar enam ratus juta rupiah)dengan jangka waktu kredit 10 Tahun atau 120 (seratus dua puluh) bulan sebagaimana Perjanjian Kredit yang dibuat dihadapan Notaris Jenmerdin, S.H. Penggugat menjaminkan 2 (dua) bidang Tanah dan Bangunan yang terletak di Kelurahan Segala Mider Kecamatan Tanjung Karang Barat Kota Bandar Lampung. Akibat Penggugat tidak mampu membayar Kredit yang telah diberikan oleh PT Bank Panin Indonesia selaku Kreditur maka dilakukan lelang dengan nilai limit sebesar Rp. 1.470.000.000 (satu milyar empat ratus tujuh puluh juta rupiah). Akibat hal tersebut Penggugat menyatakan Tergugat telah melakukan Perbuatan Melawan Hukum yang merugikan Penggugat. Lelang yang dilakukan oleh Tergugat menjadi cacat hukum karena tidak sesuai dengan Peraturan Menteri Keuangan Nomor 93/Pmk.06/2010 Tentang Petunjuk Pelaksanaan Lelang. Serta Penggugat memerintakan kepada Tergugat dan Turut Tergugat untuk membayar ganti rugi baik secara materiil dan immaterial sebesar Rp.3.500.00.000,- (Tiga milyar lima ratus juta rupuah) dan Immateriil sebesar Rp.4.000.000.000,-(Empat milyar rupiah) dengan total Rp.7.500.000.000,- (Tujuh milyar lima ratus juta rupiah)

2. Proses Penyelsaian Sengketa Gugatan Lelang Kepemilikan Sertifikat Hak Milik Nasabah Terhadap PT Bank Panin Indonesia Studi Pada Putusan No: 209/Pdt.G/2019/PN Tjk bahwa Majelis Hakim telah mengupayakan perdamaian di antara para pihak melalui mediasi sebagaimana diatur dalam Peraturan Mahkamah Agung 
Erlina, Risti Dwi Ramasari dan Rizky Ananda, Proses Penyelesaian Sengketa Gugatan Lelang Kepemilikan Sertifikat Hak Milik Nasabah terhadap PT. Bank Panin Indonesia (Studi Putusan No: 209/Pdt.G/2019/PN Tjk)

Nomor 1 Tahun 2016 tentang Prosedur Mediasi di Pengadilan dengan menunjuk Zoya Haspita, S.H., M.H., Hakim pada Pengadilan Negeri Tanjung Karang, sebagai Mediator. Bahwa berdasarkan laporan Mediator tanggal 3 September 2019, upaya perdamaian tersebut tidak berhasil. Oleh karena gugatan Perbuatan Melawan Hukum yang diajukan oleh Pengugat Fajar Sidik selaku nasabah terhadap PT Bank Panin Indonesia dinyatakan tidak dapat diterima sehingga Majelis Hakim memutus mengadili:

a. Dalam Provisi: Menolak Permohonan Provisi Penggugat.

b. Dalam Eksepsi: Menerima Eksepsi Tergugat.

c. Dalam Pokok Perkara:

1) Menyatakan gugatan Penggugat tidak dapat diterima;

2) Menghukum Penggugat untuk membayar biaya perkara yang sampai hari ini ditetapkan sejumlah Rp2.576.000,00 (dua juta lima ratus tujuh puluh enam ribu rupiah).

\section{Saran}

Berdasarkan hasil penelitian dan pembahasan penulis menberikan saran terkait dengan Studi Pada Putusan No: 209/Pdt.G/2019/PN Tjk yakni sebagai berikut:

1. BahwaHakim dalam melakukan sebuah putusan harus yang seadil-adilnya dan sesuai dengan aturan peraturan perundang-undangan yang berlaku agar tercipta kepastian hukum serta juga terciptanya tertib hukum.

2. Bagi masyarakat khususnya agar dapat lebih memahami dan memperhitungkan serta mempertimbangkan dalam mengajukan pengajuan kredit kepada lembaga perbankan karena memiliki resiko kehilangan aset yang dijaminkan kepada lembaga perbankan.

3. Bagi lembaga perbankan agar dapat memberikan penjelasan yang sangat jelas saat terjadinya perjanjian kredit yang dilakukan agar tidak terjadi gugatan sengketa karena kesalahpahaman antara lembaga perbankan selaku kreditur terhadap debiturnya di kemudian hari.

\section{DAFTAR PUSTAKA}

Abdulkadir Muhammad. 2004. Hukum dan Penelitian Hukum. Citra Aditya Bakti. Jakarta.

Adri Natar 2008. Solusi Cerdas Mengatasi Hutang Kredit. Penebar Plus. Jakarta.

Gatot Supramono. 1996. Perbankan dan Masalah Kredit Suatu Tinjauan Yuridis.Jakarta: Djambatan. Jakarta.

Malayu SP Hasibuan.2005. Dasar-Dasar Perbankan. Bumi Aksara. Jakarta.

Yudha Pandu. 2008. Himpunan Peraturan Perundang-Undangan Jaminan Fidusia dan Hak Tanggungan. Indonesia Legal Center Publishing. Jakarta. M Yahya Harahap.1996. Segi-segi Hukum Perjanjian. Alumni. Bandung. https://www.hukumonline.com/klinik/detail/ulasan/lt50294244defee/langkah-langkah-penyelesaian-kredit-macet. 